\title{
Southeast Asia in the 9th to 14th Centuries
}


The Research School of Pacific Studies is one of seven research schools in the Australian National University. It camies out research on tast and Southeast $\wedge$ sia and the Pacific Islands. Some 110 academic staff, located in ten departments and six centres, undertake work on the anthropology, economics, geography, history, international relations, languages, politics and prehistory of the region. Students are trained at Ph.D. and, in seme fields, Masters levels.

The Institute of Southeast Asian Studies was established as an autonomous organization in May 1968. It is a regional research centre for scholars and other specialists concemed with modem Southeast Asid, particularly the multi-faceted problems of slability and security, economic development, and political and social change. The Inslitule is govemed by a twenty-two-member Board of Trustees comprising nominees from the Singapore Govemment, the National University of Singapore, the various Chambers of Commerce, and professional and civic organizations. A len-man Executive Committee oversees day-to-day operations; it is chaired by the Director, the Institute's chief academic and administrative officer.

The conference at which these papers were first presented in May 1984 was sponsored by the Joint Committee on Southeast Asia of the American Council of Leamed Societies and the Social Science Research Council, together with the Research School of Pacific Studies, Australian National University. 


\title{
Southeast Asia in the 9th to 14th Centuries
}

\author{
edited by \\ David G. Marr and A.C. Milner \\ (with an introduction by Wang Gungwu)
}

INSTITUTE OF SOUTHEAST ASIAN STUDIES

SINGAPORE and the

RESEARCH SCHOOL OF PACIFIC STUDIES

AUSTRALIAN NATIONAL UNIVERSITY 
Published joinlly by

Institute of Southeast Asian Studies

Heng Mui Keng Terrace

Pasir Panjang,

Singapore 0511
Research School of Pacific Studies Australian National University PO Box 4, Canberra ACT 9.001 Australia

All rights reserved. No part of this publication may be reproduced, stored in a retrieval system, or transmilled in any form or by any means, elecironic, mechanical, photocopying, recording or otherwise, without the prior permission of the Institute of Southeast Msian Studies.

(C) 1980 Institute of Southeast Asian Studies

First reprinted 1990

Ihe responsibility for facts and opinions expressed in this publication rests exclusively with the authors and their interpretations do not necessarily reflect the views or the policy of the Research School of Pacific Studies, the Institute of Southeast Asian Studies, or their supporters.

\section{Cataloguing in Publication Data}

Southeast Asia in the 9th to 14 th centuries/editors, David G. Marr and A.C. Milner.

1. Asia, Southedstern-History-Addresses, essays, lectures.

1. Marr, David G.

II. Milner, A.C.

DS511 5721980

ISBN 9971-988-39-9 (soft cover)

ISBN 9971-988-40-2 (hard cover)

Printed in Singapore by Chong Moh Offset Printing Private Limited.

Cover illustration:

A ship from the carvings on the 8 th century Buddhist temple at Borobodur, central lava. This is thought to represent a trading and passenger vessel utilizing the monsoon winds of the Java Sea in the period of the Javanese and Sumatran Kingdoms of 500-1000 A.D.

The publishers gratefully acknowledge G. Adrian Horridge, The Design of Planked Boals of the Muluccas (London: National Maritime Museum, 1978) for the use of this illustration.] 